University of Nebraska - Lincoln

DigitalCommons@University of Nebraska - Lincoln

\title{
Food Acceptability in Field Studies with US Army Men and Women: Relationship with Food Intake and Food Choice After Repeated Exposures
}

\author{
Cees de Graaf \\ Division of Human Nutrition, Wageningen University, P.O. Box 8129, Wageningen 6700 EV, The Netherlands \\ F. Matthew Kramer \\ Behavioral Science Division, Science and Technology Directorate, US Army Natick Research Development \\ and Engineering Center, Natick, MA 01760, USA \\ Herbert L. Meiselman \\ Behavioral Science Division, Science and Technology Directorate, US Army Natick Research Development \\ and Engineering Center, Natick, MA 01760, USA
}

Larry L. Lesher

GEO-Centers, Inc. Natick, MA 01760, USA

Carol Baker-Fulco

US Army Institute of Environmental Medicine, Natick, MA 01760, USA

See next page for additional authors

Follow this and additional works at: https://digitalcommons.unl.edu/usarmyresearch

Part of the Operations Research, Systems Engineering and Industrial Engineering Commons

de Graaf, Cees; Kramer, F. Matthew; Meiselman, Herbert L.; Lesher, Larry L.; Baker-Fulco, Carol; Hirsch, Edward S.; and Warber, John, "Food Acceptability in Field Studies with US Army Men and Women:

Relationship with Food Intake and Food Choice After Repeated Exposures" (2005). US Army Research. 36. https://digitalcommons.unl.edu/usarmyresearch/36

This Article is brought to you for free and open access by the U.S. Department of Defense at DigitalCommons@University of Nebraska - Lincoln. It has been accepted for inclusion in US Army Research by an authorized administrator of DigitalCommons@University of Nebraska - Lincoln. 


\section{Authors}

Cees de Graaf, F. Matthew Kramer, Herbert L. Meiselman, Larry L. Lesher, Carol Baker-Fulco, Edward S. Hirsch, and John Warber 


\title{
Food acceptability in field studies with US army men and women: relationship with food intake and food choice after repeated exposures
}

\author{
Cees de Graaf ${ }^{a, *}$, F. Matthew Kramer ${ }^{\mathrm{b}}$, Herbert L. Meiselman ${ }^{\mathrm{b}}$, Larry L. Lesher ${ }^{\mathrm{c}}$, \\ Carol Baker-Fulco ${ }^{\mathrm{d}}$, Edward S. Hirsch ${ }^{\mathrm{b}}$, John Warber ${ }^{\mathrm{e}}$ \\ ${ }^{\mathrm{a}}$ Division of Human Nutrition, Wageningen University, P.O. Box 8129, Wageningen 6700 EV, The Netherlands \\ ${ }^{\mathrm{c}}$ Behavioral Science Division, Science and Technology Directorate, US Army Natick Research Development and Engineering Center, Natick, MA 01760, USA \\ ${ }^{\mathrm{c}}$ GEO-Centers, Inc. Natick, MA 01760, USA \\ ${ }^{\mathrm{d}}$ US Army Institute of Environmental Medicine, Natick, MA 01760, USA \\ e Department of Human Services and Consumer Sciences, Texas Southern University, Houston, TX 77004, USA
}

Received 28 July 2003; revised 12 July 2004; accepted 15 August 2004

\begin{abstract}
Laboratory data with single exposures showed that palatability has a positive relationship with food intake. The question addressed in this study is whether this relationship also holds over repeated exposures in non-laboratory contexts in more natural environments. The data were collected in four field studies, lasting 4-11 days with 307 US Army men and 119 Army women, and comprised 5791 main meals and 8831 snacks in total. Acceptability was rated on the nine point hedonic scale, and intake was registered in units of 1/4, 1/2, 3/4, or 1 or more times of the provided portion size. Correlation coefficients between individual acceptability ratings and intakes varied from 0.22 to 0.62 for the main meals $(n=193-2267)$, and between 0.13 and 0.56 for the snacks $(n=304-2967)$. The likelihood of choosing a meal for the second time was positively related to the acceptability rating of the meal when it was consumed for the first time. The results reinforce the importance of liking in food choice and food intake/choice behavior. However, the magnitude of the correlation coefficients between acceptability ratings and food intake suggest that environmental factors also have an important role in determining intake and choice.
\end{abstract}

(C) 2004 Elsevier Ltd. All rights reserved.

Keywords: Sensory; Preference; Hedonic ratings; Intake; Choice; Reliability; Validity

\section{Introduction}

Various studies have shown that there is a positive relationship between food acceptability (liking) ratings and food intake (Bellisle, Lucas, Amrani, \& Le Magnen, 1984; Bobroff \& Kissileff, 1986; de Graaf, de Jong, \& Lambers, 1999; Drewnowski, 1997; Guy-Grand, Lehnert, \& Doassans, 1994; Helleman \& Tuorila, 1991; Hetherington \& Macdiarmid, 1993; Hill \& McCutcheon, 1975; Porikos, Hessner, \& Van Italie, 1982; Spiegel, Shrager, \& Stellar, 1989; Yeomans, 1996; Zandstra, de Graaf, Van Trijp, \& Van Staveren, 1999), although this relationship is not as straightforward as it seems to be at first sight (Pérez et al.,

\footnotetext{
* Corresponding author.

E-mail address: kees.degraaf@wur.nl (C. de Graaf).
}

1994; Pliner, Herman, \& Polivy, 1990; Porikos et al., 1982; Zandstra et al., 1999). Most of these studies investigated food intake within controlled laboratory settings with foods that were artificially made highly palatable or unpalatable (e.g. Bobroff \& Kissileff, 1986; de Graaf et al., 1999; Spiegel et al., 1989; Zandstra et al., 1999). Most of the foods used in these studies would not be considered regular foods that would be consumed by the regular consumer in a naturalistic setting (e.g. Bellisle et al., 1984; Bobroff \& Kissileff, 1986; Helleman \& Tuorila, 1991; Meiselman, 1992; Zandstra et al., 1999). Correlations between acceptability and intake in a laboratory setting can be as high as 0.8-0.9 (Helleman \& Tuorila, 1991; Zandstra et al., 1999), showing that under controlled conditions acceptability has a strong relationship with intake.

Another characteristic of many of the above cited studies is that the number of exposures to the experimental foods 
Table 1

Outline of type of food services and menus (MRE's = Meals Ready to Eat) provided to US Army men and women in the four field studies used in the present analysis

\begin{tabular}{|c|c|c|c|c|c|c|}
\hline Study & Year & Location & Daily meal schedule & Length & $\begin{array}{l}\text { Meals control } \\
\text { group }\end{array}$ & Meals experimental group \\
\hline Yakima & September 1995 & $\begin{array}{l}\text { Yakima Train- } \\
\text { ing Area, WA }\end{array}$ & $\begin{array}{l}2 \text { hot meals, } \\
1 \text { MRE for lunch }\end{array}$ & 10 days & $\begin{array}{l}12 \text { menus } \\
\text { free choice }\end{array}$ & $\begin{array}{l}8 \text { potential new menus, } \\
\text { free choice }\end{array}$ \\
\hline Ranger & August 1996 & Fort Stewart, GA & 3 MRE's & 6 days & $\begin{array}{l}12 \text { menus } \\
\text { free choice }\end{array}$ & $\begin{array}{l}5 \text { breakfast menus, } 5 \text { lunch menus, } \\
5 \text { dinner menus, no choice, } \\
\text { fixed order }\end{array}$ \\
\hline Camp Parks & August 1995 & Camp Parks, CA & 3 MRE's & 4 days & $\begin{array}{l}12 \text { menus } \\
\text { free choice }\end{array}$ & $\begin{array}{l}\text { 1:5 high protein, } 2: 5 \text { high } \mathrm{CHO} \text {, } \\
\text { no choice, fixed order }\end{array}$ \\
\hline Bragg & May 1997 & $\begin{array}{l}\text { Camp MacKall, } \\
\text { NC }\end{array}$ & $\begin{array}{l}2 \text { hot meals, } 1 \text { MRE } \\
\text { for lunch } 3 \text { MRE's }\end{array}$ & $\begin{array}{l}\text { First } 4 \text { days, } \\
\text { next. } 7 \text { days }\end{array}$ & $\begin{array}{l}18 \text { menus } \\
\text { free choice }\end{array}$ & $\begin{array}{l}5 \text { breakfast, } 5 \text { lunch, } 5 \text { dinner, } \\
\text { free choice }\end{array}$ \\
\hline
\end{tabular}

was limited to a single exposure (Bobroff \& Kissileff, 1986; de Graaf et al., 1999; Guy-Grand et al., 1994; Helleman \& Tuorila, 1991; Lucas and Bellisle, 1987). As the acceptability of foods may change over time after repeated exposure (Meiselman, de Graaf, \& Lesher, 2000; Zandstra, de Graaf, Mela, \& Van Staveren, 2000), one question is whether or not the relationship between acceptability and intake remains similar over time (Zandstra et al., 2000).

There are few data on the relationship between food acceptability and food intake, which reflect non-laboratory living conditions. In early studies of the US Army food acceptability labs, it was shown that the mean acceptability ratings of foods had a strong positive association with the mean intake of those foods and the fraction of soldiers (=market share) selecting particular foods/meals in a food service context, i.e. a dining hall, or a cafetaria (Kamen, 1962; Peryam \& Pilgrim, 1957; Pilgrim, 1961; Pilgrim \& Kamen, 1963; Schutz, 1957). Cardello and Maller (1982) indicated that $25-50 \%$ of the variability in consumption was accounted for by the preference measures.

More recent survey studies, in which subjects did not actually taste and rate foods, confirm that preferences for certain foods have strong positive relationships with the (preferred or actual) consumption frequency for these foods (Drewnowski \& Hann, 1999; Stafleu, de Graaf, \& Van Staveren, 1994). Preferences for certain foods, such as high fat foods vs. low fat foods and fruit and vegetables also relate to the actual nutrient intakes in the diet, e.g. contribution of fat to energy content of the diet (Stafleu et al., 1994), or vitamin C content (Drewnowski \& Hann, 1999). These studies show that food preferences have a large impact on nutrition.

The main question addressed in the present study is whether or not the presumed positive relationship between rated acceptability and intake also holds outside the laboratory in natural eating situations. The second question addressed was whether the relationship between acceptability and intake/choice would remain stable over time, after repeated exposures to certain foods.

\section{Methods}

\section{General overview}

Data are used from four different field studies of military rations (Table 1) carried out from 1995 to 1997. These studies were selected as representative of other studies with respect to the foods used (standard rations used over the whole US Army), subject populations (men, women of various age groups, soldiers, elite troups, supporting medical staff) and environmental conditions (various parts of the USA). All studies were held in the summer with no extreme weather circumstances.

The data relevant to the current paper are those obtained on the standard, individual meals (rations) used by the United States Armed Forces, the MRE (Meal, Ready-toEat). In each study there was a control group that received the standard ration during the study, and an experimental group, which also received new items. The data comprised the daily intake of and hedonic rating for each item eaten.

\section{Subjects}

Subjects were healthy US Army men and women, participating in the field studies of the Natick Research, Development and Engineering Center (Natick), and the US Army Research Institute for Environmental Medicine

Table 2

Anthropometric characteristics (means \pm s.d.) of US Army men and women participating in field studies on food acceptability, divided by study group

\begin{tabular}{|c|c|c|c|c|c|}
\hline Study group & Subjects men/women & Age (years) & Weight (kg) & Height $(\mathrm{cm})$ & BMI $(\mathrm{kg} / \mathrm{m})$ \\
\hline Yakima, 1995 & $78 / 0$ & $26(5)$ & $80(12)$ & NA & NA \\
\hline Ranger, 1996 & $60 / 0$ & $22(3)$ & $78(14)$ & $177(6)$ & $24.7(4.0)$ \\
\hline Camp Parks, 1995 & $42 / 47$ & $32(10)$ & $70(14)$ & $170(10)$ & $24.1(3.4)$ \\
\hline Fort Bragg, 1997 & $127 / 72$ & $30(7)$ & 75 (14) & $173(10)$ & $25.0(3.4)$ \\
\hline
\end{tabular}


(hereafter called USARIEM). Table 2 gives some basic antropometric measures of the subjects.

\section{Foods}

Rations (MRE's) are made up of several standard components including a main dish (e.g. beef stew, spaghetti with meat sauce), a starch (crackers, rice), snacks/desserts (sweet and savory as well as fruit), flavour beverage bases, hot sauce, and accessory items such as salt, sugar, coffee and creamer. The main dish can be heated with a flameless ration heater, by pouring some water into a plastic pouch, giving a heat producing chemical reaction. The entire ration has typically contained 12 menus where each entree is unique and various item combinations from the remaining categories complete the menu. All the items of each meal are packed in a sealed flexible pouch. Most of the menus are identified by the name of the main dish. This analysis was restricted to the main dishes and the snacks, because they make up the vast majority of differences in meal variety, weight and energy content of the meals. The main meals and snacks included in the analyses are given in Appendix. There were about 50 different main dishes and about 70 different types of snacks across the four field studies of this paper.

\section{Procedure}

In each of the four studies subjects were issued rations on a daily basis either one per day as a lunchtime meal or three/day as the main food source (Table 1). The main purposes of these studies were to evaluate ration performance (i.e. hedonic ratings and intake) and/or to determine physiological consequences of eating a particular ration under certain conditions. Soldiers in these studies typically had a degree of choice between meals but there were not sufficient meals available to ensure that all options were present. If the subjects had a choice (see Table 1), they could get the rations at a line where the rations were made available. Subjects chose (or were issued when no choice was permitted) their rations for the day, and then they went out on duty. They came back the next day.

Data were collected on a daily basis using MRE record-cards for food intake and food acceptability. MRE record-cards consisted of preprinted forms, which named all items in the rations. Subjects entered the relative amount eaten of each item in a menu by circling one of the following alternatives: $0,1 / 4,1 / 2,3 / 4,1,2$, and 3 . These numbers reflected the proportion or number of a particular food eaten. This methods of food intake measurement has been validated against a weighted record methods in these type of field studies (Hirsch, Meiselman, \& Popper, 1985; Lichton, Miyamura, \& McNutt, 1988). The precise format of alternatives depended on the actual study group. For example, when only one meal /day was provided, the alternatives 2 and 3 were not available. In every case, subjects had the opportunity to write down a number that reflected the number of times that they ate a particular food. The number 'zero' reflected the situation that the food was handed out, but nothing was eaten of it. Food acceptability was measured for each tasted item by means of the standard nine point hedonic scale where $1=$ extremely dislike and $9=$ extremely like (Hirsch \& Kramer, 1993; Peryam, Polemis, Kamen, Eindhoven, \& Pilgrim, 1960).

Subjects were given a ration record form daily, to record how much was consumed, to make a hedonic rating for each item eaten, and to provide other data of interest for a particular food item. Subjects were seen daily by data collectors at which time records were turned in and reviewed for completeness. Subjects were also required (for at least a portion of the study) to keep all leftover food, food wrappers and the like in individually labeled plastic bags, which were provided to the study team with the completed ration-record cards. Turned in foods records and ration waste were compared to improve the validity of the information recorded by the subjects. Discrepancies between the information on the record-cards and observed waste were resolved between data collectors and subjects on subsequent data collection visits. In all studies, the menus for subsequent consumption were distributed at breakfast. The data on intake and acceptability were collected during the next day at breakfast.

\section{Data analysis}

Most analyses were done separately for each study group. This way of analysis was done to get multiple analyses of the relationship between rated acceptability and intake, and multiple analyses on the reliability of acceptability ratings. As each study group differed with respect to the foods offered and environmental circumstances in which the foods were eaten, this analysis strategy gives a clue on the stability and variability of the various relationships.

Reliability of acceptability ratings was assessed by determining the test-retest correlation coefficient, i.e. correlating the first rating to a particular food from a particular subject to the mean of the subsequent ratings for the same food of the same subject. In order to check the stability of this test-retest correlation coefficient we calculated for one study also the correlation coefficient between the first and the last time that a food was eaten by a particular person.

The relationship between acceptability and intake was assessed on two ways: (1) by determining the correlationcoefficient between all individual food item intakes and acceptability ratings, and (2) by determination of the average amount eaten (across all individual meals) as a function of the acceptability rating. The correlationcoefficient between all individual ratings and intakes included each case that a soldier ate a meal or a snack. 
So that if a given soldier over the course of the several days of the study ate 15 different main dishes, he would be represented by 15 pairs of points in the correlation coefficients. Thus, the correlation coefficient incorporated pairs of points across and within individuals. As the magnitude of the correlation-coefficients between intake and acceptability depends to a large extent on the distribution of relative intakes, we also give data on the distribution of relative intakes.

The effect of time on the acceptability-intake relationship was studied by splitting up the data of each of the four field studies into a first half and a second half. The first half represents the first exposures to foods, whereas the second half represent later exposures. The first half in the Yakima studies referred to the first 4 days, in Camp Parks the first 2 days, in the Ranger study the first half consisted of 3 days, and in the Fort Bragg study the first half comprised the first 3 days of the follow-up part of the study, and the second half comprised the last 4 days of the follow-up part of the study (see Table 1).

The relationship between acceptability and food choice was assessed by determining the chance that a particular item was chosen a second time as a function of the rating to the first time that a food was eaten. This relationship was only for determined the main dishes for those groups of subjects who had choice, and not for those who did not have a choice (see Tables 2 and 6).

\section{Results}

\section{Distributions of intakes}

Table 3 gives the distributions of relative intakes across all the studies of the present paper. By far the majority of items (87\% of the 5791 main dishes, and $86 \%$ of the 8831 snacks) were eaten completely with only a minor fraction (13-14\%) being eaten in part.

\section{Reliability of food acceptability ratings}

Table 4 shows that the test-retest correlation coefficient of the acceptability ratings varies between 0.45 and 0.89 (all $p$-values $<0.01)$ for the main dishes and between 0.41 and 0.75 (all $p$-values $<0.05$ ) for the snacks. For the Fort Bragg study, the correlation coefficients between the first and last time that subjects ate a particular item were $0.59(n=360)$ for the main dishes, and $0.44(n=429)$ for the snacks in the control group, and $0.61(n=206)$ for the main dishes and $0.70(n=318)$ for the snacks in the experimental group.

\section{Relationship between acceptability and intake}

Table 5 shows for each study group the overall correlation-coefficient between individual acceptability ratings for each main dish/snack and the amount eaten.

Table 3

Distribution of numbers of fraction of individual main meals or snack consumed

\begin{tabular}{|c|c|c|c|c|c|c|c|c|c|c|c|c|c|c|}
\hline \multirow{3}{*}{$\begin{array}{l}\text { Description of population, } \\
\text { and products }\end{array}$} & \multicolumn{14}{|c|}{ Number and percentage $(\%)$ of fraction of meals or snacks consumed } \\
\hline & \multicolumn{2}{|l|}{0.00} & \multicolumn{2}{|l|}{0.25} & \multicolumn{2}{|l|}{0.50} & \multicolumn{2}{|l|}{0.75} & \multicolumn{2}{|l|}{1.00} & \multicolumn{2}{|c|}{$\geq 2.00$} & \multicolumn{2}{|l|}{ Total } \\
\hline & No. & $\%$ & No. & $\%$ & No. & $\%$ & No. & $\%$ & No. & $\%$ & No. & $\%$ & No. & $\%$ \\
\hline \multicolumn{15}{|l|}{ Main dishes } \\
\hline Yakima control 1995 & 37 & 17 & 7 & 3 & 5 & 2 & 12 & 5 & 158 & 72 & 0 & 0 & 219 & 100 \\
\hline Yakima experimental 1995 & 30 & 10 & 7 & 2 & 10 & 3 & 11 & 4 & 240 & 81 & 0 & 0 & 298 & 100 \\
\hline Ranger control 1996 & 2 & 0 & 12 & 2 & 19 & 5 & 16 & 4 & 353 & 84 & 18 & 4 & 420 & 100 \\
\hline Ranger experimental 1996 & 0 & 0 & 21 & 4 & 31 & 5 & 23 & 4 & 489 & 86 & 3 & 1 & 567 & 100 \\
\hline Camp Parks control 1996 & 15 & 5 & 0 & 0 & 0 & 0 & 0 & 0 & 303 & 95 & 0 & 0 & 318 & 100 \\
\hline Camp Parks exp. protein 1996 & 11 & 5 & 0 & 0 & 0 & 0 & 0 & 0 & 230 & 95 & 0 & 0 & 241 & 100 \\
\hline Camp Parks exp. carbohydrate 1996 & 9 & 3 & 0 & 0 & 0 & 0 & 0 & 0 & 324 & 97 & 0 & 0 & 333 & 100 \\
\hline Fort Bragg control 1997 & 25 & 1 & 51 & 2 & 73 & 3 & 84 & 4 & 2023 & 89 & 11 & 0 & 2267 & 100 \\
\hline Fort Bragg experimental 1997 & 17 & 2 & 55 & 5 & 61 & 5 & 69 & 6 & 908 & 80 & 18 & 2 & 1128 & 100 \\
\hline Total main meals & 146 & 3 & 153 & 3 & 199 & 3 & 215 & 4 & 5028 & 87 & 50 & 1 & 5791 & 100 \\
\hline \multicolumn{15}{|l|}{ Snacks } \\
\hline Yakima control 1995 & 77 & 21 & 2 & 1 & 9 & 3 & 5 & 1 & 273 & 73 & 8 & 2 & 374 & 100 \\
\hline Yakima experimental 1995 & 68 & 13 & 12 & 2 & 8 & 2 & 7 & 1 & 413 & 80 & 9 & 2 & 517 & 100 \\
\hline Ranger control 1996 & 4 & 1 & 11 & 2 & 13 & 2 & 8 & 1 & 523 & 83 & 69 & 11 & 628 & 100 \\
\hline Ranger experimental 1996 & 4 & 0 & 36 & 3 & 27 & 2 & 20 & 2 & 1049 & 91 & 14 & 1 & 1150 & 100 \\
\hline Camp Parks control 1996 & 19 & 5 & 0 & 0 & 0 & 0 & 0 & 0 & 387 & 93 & 10 & 2 & 416 & 100 \\
\hline Camp Parks exp. protein 1996 & 22 & 5 & 0 & 0 & 0 & 0 & 0 & 0 & 409 & 91 & 16 & 4 & 447 & 100 \\
\hline Camp Parks exp. carbohydrate 1996 & 19 & 4 & 0 & 0 & 0 & 0 & 0 & 0 & 390 & 90 & 22 & 5 & 431 & 100 \\
\hline Fort Bragg control 1997 & 125 & 4 & 85 & 3 & 105 & 4 & 53 & 2 & 2553 & 86 & 46 & 2 & 2967 & 100 \\
\hline Fort Bragg experimental 1997 & 47 & 2 & 78 & 4 & 97 & 5 & 44 & 2 & 1616 & 85 & 19 & 1 & 1901 & 100 \\
\hline Total snacks & 385 & 4 & 224 & 3 & 259 & 3 & 137 & 2 & 7613 & 86 & 213 & 2 & 8831 & 100 \\
\hline
\end{tabular}

The main meal or snacks were part of rations (MRE's). 
Table 4

Test-retest correlation coefficient between acceptability rating of foods tasted for the first time, and the average of the subsequent ratings

\begin{tabular}{llr}
\hline $\begin{array}{l}\text { Description of population } \\
\text { and products }\end{array}$ & $\begin{array}{l}\text { Test-retest } \\
\text { correlation coefficient }\end{array}$ & $n$ \\
\hline Main dishes & & \\
Yakima control 1995 & 0.89 & 37 \\
Yakima experimental 1995 & 0.74 & 64 \\
Ranger control 1996 & 0.45 & 116 \\
Ranger experimental 1996 & 0.68 & 83 \\
Camp Parks control 1995 & 0.59 & 66 \\
Camp Parks protein 1995 & 0.58 & 91 \\
Camp Parks carbohydrate 1995 & 0.74 & 133 \\
Fort Bragg control 1997 & 0.55 & 489 \\
Fort Bragg experimental 1997 & 0.68 & 274 \\
Snacks & & \\
Yakima control 1995 & 0.65 & 62 \\
Yakima experimental 1995 & 0.41 & 93 \\
Ranger control 1996 & 0.50 & 171 \\
Ranger experimental 1996 & 0.67 & 240 \\
Camp parks control 1995 & 0.64 & 72 \\
Camp parks protein 1995 & 0.61 & 112 \\
Camp parks carbohydrate 1995 & 0.61 & 113 \\
Fort Bragg control 1997 & 0.62 & 647 \\
Fort Bragg experimental 1997 & 0.75 & 461 \\
\hline
\end{tabular}

The correlation coefficients vary from 0.22 to 0.62 (all $p$-values $<0.01)$ for the main meals, and between 0.1 and 3 and 0.56 (all $p$-values $<0.01$ ) for the snacks.

Table 5 also distinguishes between the correlationcoefficients between intake and acceptability during the first half of the field studies and the second half of the field studies. Table 5 indicates that there were no systematic differences between the first half correlations and second half correlations. The maximum number of times that an item (either a main meal or a snack) was eaten by an individual was six for the Ranger and Camp Parks studies, eight for the Yakima study, and 14 for the Fort Bragg study.

Table 6 shows the mean relative amount eaten as a function of the acceptability rating. It shows that the virtually all meals and snacks which scored 7 or higher on acceptability were completely eaten. From the meals that rated 5 or less, on average less than $90 \%$ was eaten. From the meal which were rated as 'dislike extremely' $(=1)$, on average about half was eaten.

\section{Relationship between acceptability and choice}

The right part of Table 6 shows the effect of the rating given to a food when tasted for the first time on the chance of selecting it again. It shows that this chance increases when the acceptability gets higher. When a meal was rated 'four' or lower when eaten for the first time, there was a little chance $(<25 \%)$ that it was chosen again. When it was rated an 'eight' or a 'nine' the first time, the chance that is was chosen again was about $50 \%$.

\section{Discussion}

It is concluded that in a naturalistic setting, food acceptability plays an important role in food intake and food choice, but it is by no means the dominant factor in intake. The magnitude of the correlation-coefficient between acceptability and intake shows that the acceptability ratings could only explain a small part of the variance in food intake. This implies that other factors are just as or even more important than the hedonic factors. In the last decade, it has become increasingly clear that food intake

Table 5

Correlation coefficients between individual acceptability rating of foods and relative amount eaten

\begin{tabular}{|c|c|c|c|c|c|c|}
\hline Subjects group/main dish, snack & $\begin{array}{l}\text { Overall } \\
\text { correlation coefficient }\end{array}$ & $n$ & $\begin{array}{l}\text { First half } \\
\text { correlation coefficient }\end{array}$ & $n$ & $\begin{array}{l}\text { Second half } \\
\text { correlation coefficient }\end{array}$ & $n$ \\
\hline \multicolumn{7}{|l|}{ Main dishes } \\
\hline Yakima control 1995 & 0.62 & 196 & 0.62 & 101 & 0.61 & 95 \\
\hline Yakima experimental 1995 & 0.57 & 282 & 0.43 & 126 & 0.67 & 156 \\
\hline Ranger control 1996 & 0.34 & 426 & 0.30 & 228 & 0.39 & 198 \\
\hline Ranger experimental 1996 & 0.40 & 588 & 0.42 & 314 & 0.40 & 274 \\
\hline Camp Parks control 1995 & 0.45 & 300 & 0.44 & 155 & 0.46 & 145 \\
\hline Camp Parks protein 1995 & 0.22 & 227 & 0.15 & 116 & 0.28 & 111 \\
\hline Camp Parks carbohydrate 1995 & 0.49 & 327 & 0.60 & 172 & 0.24 & 155 \\
\hline Fort Bragg control 1997 & 0.44 & 1604 & 0.40 & 748 & 0.48 & 856 \\
\hline Fort Bragg experimental 1997 & 0.55 & 834 & 0.53 & 399 & 0.59 & 435 \\
\hline \multicolumn{7}{|l|}{ Snacks } \\
\hline Yakima control 1995 & 0.45 & 287 & 0.52 & 159 & 0.33 & 140 \\
\hline Yakima experimental 1995 & 0.39 & 447 & 0.40 & 215 & 0.38 & 232 \\
\hline Ranger control 1996 & 0.24 & 620 & 0.30 & 340 & 0.13 & 280 \\
\hline Ranger experimental 1996 & 0.39 & 1202 & 0.46 & 645 & 0.31 & 557 \\
\hline Camp Parks control 1995 & 0.45 & 332 & 0.58 & 157 & 0.25 & 175 \\
\hline Camp Parks protein 1995 & 0.26 & 350 & 0.39 & 187 & 0.08 & 163 \\
\hline Camp Parks carbohydrate 1995 & 0.13 & 343 & 0.24 & 183 & 0.01 & 160 \\
\hline Fort Bragg control 1997 & 0.31 & 1816 & 0.34 & 829 & 0.26 & 987 \\
\hline Fort Bragg experimental 1997 & 0.56 & 1219 & 0.61 & 607 & 0.43 & 612 \\
\hline
\end{tabular}


Table 6

Relative amount eaten, and chance of selecting the meal at least a second time as function of acceptability ratings

\begin{tabular}{|c|c|c|c|c|c|}
\hline Acceptability rating & Amount eaten ${ }^{\mathrm{a}}$ & $n^{\mathrm{a}}$ & Frequency rating first time ${ }^{b}$ & Frequency of meals eaten $>1$ & Chance $\%$ \\
\hline 1 & 0.46 & 148 & 75 & 6 & 8 \\
\hline 2 & 0.60 & 89 & 54 & 6 & 11 \\
\hline 3 & 0.73 & 95 & 59 & 10 & 17 \\
\hline 4 & 0.77 & 182 & 106 & 26 & 25 \\
\hline 5 & 0.87 & 294 & 154 & 48 & 31 \\
\hline 6 & 0.92 & 596 & 332 & 84 & 25 \\
\hline 7 & 0.96 & 1168 & 665 & 213 & 32 \\
\hline 8 & 1.00 & 1638 & 767 & 329 & 43 \\
\hline 9 & 1.00 & 1497 & 601 & 315 & 52 \\
\hline
\end{tabular}

a Yakima control, Yakima experimental, Ranger control, Ranger experimental, Camp Parks control, Camp Parks Protein, Camp Parks Carbohydrate group, Fort Bragg control, Fort Bragg experimental.

b Yakima control, Yakima experimental, Ranger control, Camp Parks control, Fort Bragg control, Fort Bragg experimental.

and food choice are governed by a complex interaction between a person, the food and the environment. Environmental factors, which have been shown to have strong effects on food intake, include the easy access to foods, the physical environments, the social environment, and economic and cultural factors. The main results of the present study show that acceptability ratings of foods in field studies have a positive relationship with food intake and food choice to a significant degree. Apparently, the relationship between food acceptability and food intake is robust enough to be demonstrated in field studies, in which the investigators have little control about what, how, when, and under which circumstances foods are eaten. We think that the observed consistency in the correlation-coefficients is striking, considering the number of factors that would tend to obscure the relationship between acceptability and intake. All subjects were in training and were often not in a position to eat when they wanted to eat. The physical and social conditions of the meals varied from one meal to the next. Sometimes people were having their meal alone in the field in all sorts of weather conditions, and sometimes meals were comfortably eaten on the field with a group of people. In some cases the meals could not be heated, or there was no water available to add to some of the meal components. In some instances meals were eaten with tight time constraints, whereas other meals could be eaten in a more relaxed way. About $85 \%$ of all meals and snacks were eaten completely, and just a small fraction (13-14\%) was eaten for less than $100 \%$. All these factors tend to increase the error in the measurement of both intake and acceptability. Therefore, these results reinforce the importance the role of hedonic factors of food intake and food choice.

The range of values of correlation-coefficients between acceptability and intake in this study are lower than the observed correlation between acceptability and intake in a number of laboratory studies, where correlations were found in the range from 0.5 to 0.9 (Helleman \& Tuorila, 1991; Zandstra et al., 1999). The magnitude of the observed correlations is similar to the range of values of correlationcoefficients (0.26-0.48) between taste (liking) and energy intake of meals and snacks reported by Feunekes, de Graaf, and Van Staveren (1995), and Meiselman et al. (2000). Feunekes et al. (1995) also studied food intake in a natural or non-laboratory setting, where subjects rated the liking of each meal/snack they consumed during a number (four or seven) of consecutive days. The study of Meiselman et al. (2000) was also carried out under realistic conditions, where subject sat in a dining room and ate as little or as much as they wanted. This finding confirms the notion that correlations between acceptability and intake are higher in a controlled laboratory environment than under more realistic conditions.

Although we consider the field conditions in this study as natural because of the (limited) freedom of choice and the variety of physical and social conditions, these conditions are not typical of the normal living situation in everyday life of consumers in the industrialized world. Consumers in real life settings have a larger degree of choice, and usually consume their meals in comfortable physical and social conditions with family and/or friends. In realistic situations, most consumers will generally choose the foods they like, be able to prepare the foods in an appropriate way, and compose meals with an approriate combination of foods.

Although consumers in the real world have an enormous variety (thousands) of products to choose from, the actual variety in their diets is not so much varied. A study from Drewnowksi et al. (1997) showed that under normal living conditions the total number of different food items eaten across a week was on average about 25-60. In a recent study of Hirsch, Kramer, and Meiselman (2004), it was found that soldiers in two field studies consumed on average 25 (one study) or 48 (other study) different foods during approximately one week. These numbers are not much lower than the numbers from the study of Drewnowski et al. (1997). Therefore, we hold the view that these data can have an indicative value for the correlation between acceptability and intake in real life settings.

The relationship between acceptability and intake was stable across the first half of the field studies and the second half of the field studies. This finding indicates that the relationship between acceptability and intake was about constant over the 4-11 days of these studies, and did not 
change as a function of repeated exposure. Of course, this finding does not preclude that the acceptabilities of the foods themselves changed over time. This finding is also in line with Feunekes et al. (1995), data on the relationship between acceptability and intake.

The reliability of the acceptability ratings as measured by the test-retest reliability is moderately high, given the number of factors that would negatively influence the reliability. It is well known that palatability of a particular food may depend on environmental and nutritional circumstances (see also discussion in the first paragraph of this section). Therefore, part of the variance in acceptability ratings is due to systematic variation in palatability as function of the changing circumstances. This variance will lower the estimation of the test-retest reliability.

This study shows that acceptability has an effect on food intake and on food choice in realistic circumstances. Meals that were not liked (rating $<5$ ) were often not completely $(<77 \%)$ consumed. Meals that were not liked (rating $<5)$ also less chosen $(<31 \%)$ for the second time. It should be kept in mind that the men and women in these studies had some freedom of choice, but could not always choose whatever they wanted. In many laboratory studies subjects are required or expected to eat the foods presented. The soldiers in this study had the choice to eat as much or as little as they wanted. In particular circumstances not all possible menus were available. This condition is also realistic for civilian life, when family members cannot always chose what they will eat. In this study, this condition also implied that subjects had to take and eat less acceptable foods. These circumstances will also tend to mask clear relationship between acceptability ratings on the one hand and intake on the other hand.

The vast majority of entrees and snacks that were consumed were consumed as a whole. This result indicates that people will mostly 'clean their plate', and eat from a particular dish until nothing is left. Another factor is that the field situation where subjects were asked to keep the leftover is not conducive to saving leftover. This supports more cognitive/environmental explanations versus more physiological explanations of food intake. If people would regulate intake solely on the basis of internal physiological cues, one would expect a more wide and evenly distribution of consumed portion sizes.

One drawback of the present way of data collection is that the encircled amount eaten on the preprinted form and the rated acceptability were done at the same time. This may lead to a tendency towards cognitive consistency in which rated preferences is brought in congruence (rationalized) with the amount eaten, possibly producing a positive bias in the values of the correlations coefficients. There is no easy solution for this issue. To rate acceptability and intake at independent occasions would also lead to other influences at the different occasions, both on the intake side and the rated acceptability side. In an earlier ration study, subjects were asked to rate all food items consumed on a questionnaire that was completed at the end of the study (Jezior, Lesher, \& Popper, 1990). During the study subjects also rated the items in the way as was done in the present field studies. A comparison of study ratings with post study rating showed that the post study ratings were lower, but the relative acceptance ratings remained constant (Jezior et al., 1990). This finding indicates that the cognitive dissonance drawback may not be that serious.

The average amount consumed as a function of the acceptability ratings show that in many cases people consume items that they do not like. Apparently there must some reason for these subjects to eat things that they do not like. One obvious reason is that subjects eat in order reduce (expected) unpleasant feeling of hunger. Other factors could also play a role in this, for example, it might be considered as inappropriate in a social setting not to clean your plate. Another reason could refer to convenience. Soldiers were requested to keep the leftovers for later inspection. This could be inconvenient to them, which may be a reason for eating the foods completely.

This study showed that acceptability plays an important role in food intake and food choice, but that is by no means the dominant factors. Further research in these environmental factors that determine intake and choice is appropriate if we want to predict intake and choice in the real world.

\section{Acknowledgements}

This review contributes to a second Special Section on US Army Research, originally conceived by H.L. Meiselman, F.M. Kramer, J. Dwyer, and D. Booth, and guestedited by P. Pliner, H.L. Meiselman, and F.M. Kramer. The first Special Section on US Army Research appeared in 2003, Volume 40, Number 3.

\section{Appendix}

Main dishes and snacks provided in field rations to US Army men and women, included in the present analysis

\begin{tabular}{ll}
\hline Main dishes & Snacks \\
\hline Yakima control & \\
Pork with rice & Oatmeal cookie bar \\
Corned Beef Hash & Potato sticks \\
Omelet w/ham & Chocolate covered cookie \\
Spaghetti with meat sauce & Chocolate covered brownie \\
Smoky Franks & Vanilla pound cake \\
Beef stew & Lemon pound cake \\
Ham Slices & Pineapple pound cake \\
Pork Chow Mein & Chocolate mint pound cake \\
Tuna with Noodles & Orange pound cake \\
Chicken with Rice & Charms \\
Escaloped Potatoes with Ham & M\&M's \\
& Chocolate bar
\end{tabular}

(continued on next page) 


\begin{tabular}{|c|c|}
\hline Main dishes & Snacks \\
\hline & Vanilla Caramels \\
\hline & Tootsie Rolls \\
\hline \multicolumn{2}{|l|}{ Yakima experimental } \\
\hline Teriyaki Beef & Corn chips \\
\hline Meatloaf w/Gravy & Beef Jerky \\
\hline Beef Enchiladas & Snack mix \\
\hline Spicy Oriental Chicken & Roasted Peanuts \\
\hline Salsa Chicken & Lemon Pound Cake \\
\hline Pasta Primavera Alfredo & Short bread cookies \\
\hline Black Beans and Rice Burrito & Fudge Brownie \\
\hline \multirow[t]{9}{*}{ Sausage Patty } & Apple Cinnamon Toaster Pastry \\
\hline & Chewy chocolate bar \\
\hline & Apple fruit filled bar \\
\hline & Blueberry fruit filled bar \\
\hline & Strawberry fruit filled bar \\
\hline & Peanut Butter Granola bar \\
\hline & Chocolate Chip Granola bar \\
\hline & Honey nut Granola bar \\
\hline & Cinnamon Apples \\
\hline \multicolumn{2}{|l|}{ Camp Parks-control } \\
\hline Pork with rice & Tavern nuts \\
\hline Spaghetti with meat sauce & Oatmeal Cookie Bar \\
\hline Ham Slices & Chocolate Mint Pound Cake \\
\hline Tuna with Noodles & Orange Pound Cake \\
\hline Chicken with Rice & Potato Sticks \\
\hline Escaloped Potatoes with ham & Chocolate Covered Cookie Bar \\
\hline Chili macaroni & Vanilla Pound Cake \\
\hline Chicken Stew & Lemon Pound Cake \\
\hline Grilled Chicken & Chocolate covered Brownie \\
\hline Smoky Franks & Vanilla Caramels \\
\hline Beef Stew & Tootsie Rolls \\
\hline \multirow[t]{2}{*}{ Pork Chow Mein } & M\&M's \\
\hline & Charms \\
\hline \multicolumn{2}{|c|}{ Camp Parks-experimental protein } \\
\hline Spaghetti with Meat Sauce & Brownie \\
\hline Ham slices & Oatmeal Cookie Bar \\
\hline Pork with Rice and Barbeque & Chocolate Mint Pound Cake \\
\hline \multicolumn{2}{|l|}{ Sauce } \\
\hline Beef Steak & Orange Pound Cake \\
\hline Chicken Breast Fillet & Vanilla Pound Cake \\
\hline \multirow[t]{4}{*}{ Chicken with Rice } & Potato Sticks \\
\hline & Tavern Nuts \\
\hline & Ham Jerky \\
\hline & Beef Jerky \\
\hline
\end{tabular}

Camp Parks-experimental carbohydrate Pasta Primavera Chicken Stew Cheese Tortelini Pork Chow Mein and Noodles Rice and Bean Burrito Chili Macaroni

\section{Brownie}

Chocolate Covered Brownie Chocolate Mint Pound Cake Orange Pound Cake Vanilla Pound Cake Lemon Pound Cake Charms

M\&M's Oatmeal Cookie bar Caramels Chocolate Bar Tootsie Rolls

Ranger Control See Camp Parks control group.

Ranger Experimental

Pasta Primavera

Chicken Stew

Cheese Tortellini

Pork Chow Mein
Nutrigrain Cereal Bar

Almond Dairy Bar

Apple Toaster pastry

Strawberry Toaster Pastry

\begin{tabular}{|c|c|}
\hline Main dishes & Snacks \\
\hline Meatloaf with Gravy & Fig Bar \\
\hline Tuna Salad & Strawberry Dairy Bar \\
\hline Pocket Peanut Butter and Fluff & Strawberry Fruit Roll Up \\
\hline Chunky Chicken & Jack Beef Steak \\
\hline Pocket Peanut Butter and Jelly & Chocolate Pudding \\
\hline Pocket Barbecue Chicken & Cheese Curls \\
\hline Sausage Patty & Oatmeal Cookie \\
\hline Cereal with Milk & Garlic Bagel Chips \\
\hline Frosted Flakes with Milk & Jelly Candy \\
\hline Egg and Ham & Potato Sticks \\
\hline Pocket Biscuit and Sausage & Cheddar Gold Fish \\
\hline \multirow[t]{16}{*}{ Nacho Beef Pocket } & Cheese and Crackers \\
\hline & Caramel Popcorn Bar \\
\hline & Cheese and Peanut Butter Crackers \\
\hline & Butterscotch E-bar \\
\hline & Lorna Doone Cookies \\
\hline & Charms \\
\hline & Skittles \\
\hline & Chocolate Mint Cookie \\
\hline & Vanilla Pound Cake \\
\hline & Lemon Pound Cake \\
\hline & Lemon Poppy Cake \\
\hline & Chocolate Mint Cake \\
\hline & M\&M Mars Munch bar \\
\hline & Shortbread Cookie \\
\hline & Nutter Butter Cookies \\
\hline & Wheaties Cereal Bar \\
\hline
\end{tabular}

Fort Bragg control

Beef Steak

Chicken Stew

Ham Slices

Chicken with Noodles

Smoky Franks

Pork Chow Mein

Chicken with Rice

Beef Stew

Chili Macaroni

Pasta with Vegetables

Cheese Tortellini

Pork with Rice

Grilled Chicken

Tuna with Noodles

Beef Ravioli

Turkey breast with gravy

and potatoes

Beef with Mushrooms

Spaghetti with Meat Sauce

Fort Bragg Experimental

Pasta Primavera Alfredo

Meatloaf with Onion Gravy

Chicken Stew

Pork Chow Mein

Cheese Tortelini

Pocket Barbecue Chicken

Pocket Nacho Cheese

Pocket Peanut Butter and Jelly

Pocket Pepperoni

Tuna Salad

Chunky Chicken

Eggs and Ham

Frosted Flakes with Milk

Oatmeal
Tavern Nuts

Potato Sticks

Corn Chips

Cheese Curls

Fig Bar

Chocolate Covered Cookie

Fudge Brownie

Granola bar

Pound Cake, different flavors

Jolly Ranger Candy

Heat Stable M\&M's

Peanut Munch Bar

Skittles

Vanilla caramels

Tootsie Rolls
Apple Toaster Pastry
Nutrigrain Cereal Bar
Pound cake different flavors
Chocolate E-bar
Potato Sticks
Beef Stick Jerky
Cheddar Goldfish
Caramel Popcorn Bar
Lorna Doone Cookies
Hooah Peanut Butter Bar
Hooah Raspberry Bar
Hooah Apple Cinnamon Bar
Lemon Poppy Cake
Starch Jelly candy
Peanut Munch Bar
Vanilla Caramels
$\quad$ (continued on next page) 


\begin{tabular}{ll}
\hline Main dishes & Snacks \\
\hline & Charms \\
Cheese and Wheat Crackers \\
Chocolate Covered Cookie \\
Chuckles \\
Nutter Butter Cookies \\
Plain Flat Bread \\
Tomato and Herb Flat Bread \\
Shortbread Cookies
\end{tabular}

\section{References}

Bellisle, F., Lucas, F., Amrani, R., \& Le Magnen, J. (1984). Deprivation, palatability and the micro-structure f meals in human subjects. Appetite, $5,85-94$.

Bobroff, E. M., \& Kissileff, H. R. (1986). Effects of changes in palatability on food intake and the cumulative food intake curve in man. Appetite, 7 , $85-96$.

Cardello, A. V., \& Maller, O. (1982). Relationships between food preferences and food acceptance ratings. Journal of Food Science, $47,1553-1557$.

de Graaf, C., de Jong, L., \& Lambers, A. (1999). Palatability affects satiation but not satiety. Physiology and Behavior, 66, 681-688.

Drewnowski, A. (1997). Taste preferences and food intake. Annual Review of Nutrition, 17, 237-253.

Drewnowski, A., \& Hann, C. (1999). Food preferences and reported frequencies of food consumption as predictors of current diet in young women. American Journal of Clinical Nutrition, 70, 28-36.

Feunekes, G. I. J., de Graaf, C., \& Van Staveren, W. A. (1995). Social facilitation of food intake is mediated by meal duration. Physiology and Behavior, 58, 551-558.

Guy-Grand, B., Lehnert, V., \& Doassans, M. (1994). Type of test-meal affects palatability and eating style in humans. Appetite, 22, 125-134.

Helleman, U., \& Tuorila, H. (1991). Pleasantness rating and consumption of open sandwiches with varying $\mathrm{NaCl}$ and citric acid contents. Appetite, 17, 229-238.

Hetherington, M. M., \& Macdiarmid, J. I. (1993). Pleasure and Excess: Liking for and overconsumption of chocolate. Physiology and Behavior, 37, 27-35.

Hill, S. W., \& McCutcheon, B. (1975). Eating responses of obese and nonobese humans during dinner meals. Psychosomatic Medicine, 37, 395-401.

Hirsch, E. S., Meiselman, H. L., Popper, R. D., Smits, G., Jezlor, B., Lichton, I., Wenkam, N., Burt, J., Fox, M., McNutt, S., Thiele, M. N., \& Dirige, O. (1985). The effects of prolonged feeding meal ready to eat (MRE) operational rations Technical report Natick TR-85/035. Natick MA: US Army Natick Research, Development and Engineering Center.

Hirsch, E. S., \& Kramer, F. M. (1993). Situational influences on food intake. In M. Marriot, \& F. M. Kramer (Eds.), Nutritional needs in hot environments (pp. 215-243). Washigton, DC: National Academy Press.

Hirsch, E. S., Kramer, F. M., \& Meiselman, H. L. (2004). Effects of food attributes and feeding environments on acceptance, consumption and body weight: Lessons learned in a twenty-year program of military ration research. Appetite, (this issue. doi:10.1016/j.appet.2004.04.010).
Jezior, B. A., Lesher, L. L., \& Popper, R. D. (1990). The relationship of recent and retrospective food acceptance ratings. Food Quality and Preference, 2, 21-27.

Kamen, J. M. (1962). Reasons for nonconsumption of food in the Army. Journal of the American Dietetic Association, 41, 437-437.

Lichton, I. J., Miyamura, J. B., \& McNutt, S. W. (1988). Nutritional evaluation of soldiers subsisting on meal, ready-to-eat operational rations for an extended period: Body measurements, hydration, and blood nutrient. American Journal of Clinical Nutrition, 48, 30-37.

Lucas, F., \& Bellisle, F. (1987). The measurement of food preferences in humans: Do taste-and-spit test predict consumption. Physiology and Behavior, 39, 739-743.

Meiselman, H. L. (1992). Methodology and theory in human eating research. Appetite, 19, 49-55.

Meiselman, H. L., de Graaf, C., \& Lesher, L. (2000). The effects of variety and monotony on food acceptance and intake at a midday meal. Physiology and Behavior, 70, 119-125.

Pérez, C., Dalix, A. M., Guy-Grand, B., \& Bellisle, F. (1994). Human responses to five concentrations of sucrose in a dairy product: Immediate and delayed palatability effects. Appetite, 23, 165-178.

Peryam, D. R., \& Pilgrim, F. J. (1957). Hedonic scale method of measuring food preferences. Food Technology, 11, 9.

Peryam, D. R., Polemis, B. W., Kamen, J. M., Eindhoven, J., \& Pilgrim, F. J. (1960). Food preferences of men in the US Armed Forces. Chicago: Quartermaster Food and Container Institute.

Pilgrim, F. J. (1961). What foods do people accept or reject? Journal of the American Dietetic Association, 38, 439-443.

Pilgrim, F. J., \& Kamen, J. M. (1963). Predictors of human food consumption. Science, 355, 501-502.

Pliner, P., Herman, C. P., \& Polivy, J. (1990). Palatability as a determinant of eating: Finickiness as a function of taste, hunger and the prospect of good food. In E. D. Capaldi, \& T. L. Powley (Eds.), Taste, experience, and feeding (pp. 210-226). Washington, DC: American Psychological Association.

Porikos, K. P., Hessner, M. F., \& Van Italie, T. B. (1982). Caloric regulation in normal-weight men maintained on a palatable diet of conventional foods. Physiology and Behavior, 29, 293-300.

Schutz, H. G. (1957). Performance ratings as predictors of consumption. American Psychologist, 12, 380-380.

Spiegel, T. A., Shrager, E. E., \& Stellar, E. (1989). Responses of lean and obese subjects to preloads, deprivation, and palatability. Appetite, 13, 45-69.

Stafleu, A., de Graaf, C., \& Van Staveren, W. A. (1994). Attitudes towards high fat foods and their low fat alternatives: Reliability and relationship with relative fat intake. Appetite, 22, 183-196.

YeomansYeomans, M. R. (1996). Palatability and the micro-structure of feeding in humans: The appetizer effect. Appetite, 27, 119-133.

Zandstra, E. H., de Graaf, C., Mela, D. A., \& Van Staveren, W. A. (2000). Short and long-term effects of changes in pleasantness on food intake. Appetite, 34, 253-260.

Zandstra, E. H., de Graaf, C., Van Trijp, H. C. M., \& Van Staveren, W. A. (1999). Laboratory hedonic rating as predictor of consumption: Three brief-exposure tests compared to an ad libitum consumption test. Food Quality and Preference, 10, 411-418.

Zandstra, E. H., de Graaf, C., Van Trijp, H. C. M., \& Van Staveren, W. A. (2000). Effects of variety and repeated in-home consumption on product acceptance. Appetite, 35, 113-119. 